\title{
Giving Exclusive ASI to Samin Community in Japanese Central Desa Margomulyo Kecamatan Margomulyo Bojonegoro District
}

\author{
Andin Ajeng Rahmawati ${ }^{1}$, \\ Nurwijayanti², \\ Indasah $^{2}$ \\ ${ }^{1}$ Magister of Health Study \\ Program of Institut Ilmu Kesehatan \\ STRADA Indonesia \\ ${ }^{2}$ Lecturer of Institut Ilmu \\ Kesehatan STRADA Indonesia \\ Email: \\ andinajeng88@gmail.com
}

Received: October 12, 2019

Accepted : February 13, 2020

Published : May 12, 2020

\begin{abstract}
ASI is the best nutrition for babies that must be given until the age of 2 years. But at 6 months the baby needs to get additional food. Complementary food for breast milk or solids starts to be given at the age of 6 months because the digestive process of babies who have started is perfect. ASI companion needs to be done to fulfill the baby's nutrition. The Samin community has its own local knowledge regarding infant feeding. The provision of complementary breastfeeding is associated with knowledge of pusak pusak which is the standard for the Samin community in providing complementary food for babies, the dizziness occurs at the age of babies reaching 5 to 7 days, so the baby's belly button will fall or fall and this event is called the pusak puser. The purpose of this study is to know and describe exclusive breastfeeding for mothers who have infants under 2 years of age and describe the practices of mothers in exclusive breastfeeding and supplementary food for infants in the Samin community. The research design used was qualitative ethnography with a phenomenology approach. Data collection uses in-depth interview techniques with semi-structured questions. The sampling technique in this study used purposive sampling with a sample of 15 informants from 30 informants. The results of the study show that local beliefs and culture influence exclusive breastfeeding and will have less impact on both breastfeeding mothers and infants. In the process of implementing this research are influenced by several factors including internal factors and external factors. Internal factors include maternal characteristics (age, parity, education, work), knowledge, trust while external factors include support from health workers (counseling, policies, recording and reporting systems) and family support.
\end{abstract}

Keywords: Exclusive breastfeeding, Nutrition, Baby

This is an open-acces article distributed under the terms of the Creative Commons Attribution-ShareAlike 4.0 International License. 


\section{INTRODUCTION}

Until now, ASI is still the best nutrition for babies that must be given until the age of 2 years. But at 6 months the baby needs to get additional food. ASI complementary foods or called MPASI starts to be given at the age of 6 months because the digestive process of babies who have started is perfect (Maya Fitria, 2011).

Children, especially in infancy, must absolutely have optimal nutritional status for good health and growth in the future. Mother's Milk (ASI) is the safest, hygienic, practical and economic baby food that is very supportive for optimal growth and development of babies. Mother's milk is the only perfect food to guarantee the growth of babies in the first six months. In addition, in the correct breastfeeding process, the baby will get good physical, emotional and spiritual development in his life (Saleha, 2012).

In the Samin community, mothers have given additional food before the age of six months, one example of giving the ASI supplement for the first time to children is by giving water, giving tea and providing additional food such as bread, biscuits, bananas and rice that has been chewed by the mother, then give it to the baby. There is also giving food consumed by his mother by chewing on food consumed by the mother and giving a little to her child which aims to establish affection with the child. The Samin community also believes that children who have been born into the world also have sustenance to eat.

According to Astutik, factors that can affect the failure of exclusive breastfeeding are, sociocultural factors, family or husband support, maternal physical factors, psychological factors, infant factors, health personnel factors and increased promotion of formula milk (Astutik, 2014).

The Samin community has values that they believe in regulating their lives. The values that they believe in one of them are the values that govern their lives in feeding children. In the Samin community, the guideline is from the habits that have been patterned since their ancestors, that the guidelines for feeding children can be seen from the tradition of pusak puser. This is considered as values that can be used as a benchmark for the community in providing complementary food for breast milk for babies. Based on the data the researchers got from 15 breastfeeding mothers, only 10 people gave exclusive breastfeeding to their babies.

The government sets this standard to set the deadline for exclusive breastfeeding for infants. While the community has the knowledge and standards that they set themselves, especially in the provision of complementary breastfeeding.

\section{METHODS}

In this study using ethnographic qualitative methods by conducting in-depth interviews is to obtain more in-depth information about exclusive breastfeeding, making it possible to obtain implied information (insigh) regarding attitudes, beliefs, motivations and behavior of the target population. The informants in this study were 30 people. The sample size in the study amounted to 15 people. Data was collected using question sheets, recording informant interviews with mobile phones and recording them in notebooks and then analyzing and making transcripts and triangulation.

\section{RESULT}

The results of this study get an overview related to the analysis of the program of Exclusive Breastfeeding in Japanese Hamlet Margomulyo Village, Bojonegoro Regency. From this research, the themes are:

1. Mother's knowledge about giving exclusive breastfeeding in Japanese hamlet, Margomulyo Village, Bojonegoro Regency.

2. Mother's opinion regarding the provision of Exclusive ASI in Japanese Hamlet, Margomulyo Village, Bojonegoro Regency.

3. The right technique for breastfeeding by mothers who have babies under 2 years in Japanese Hamlet Margomulyo Village, Bojonegoro Regency.

4. The allocation of time for babies may be given complementary foods in Japanese Hamlet, Margomulyo Village, Bojonegoro Regency.

5. Advantages of Exclusive ASI according to mothers who have babies under 2 years in Japanese Hamlet Margomulyo Village, Bojonegoro Regency. 
6. The food given by the mother to the ASI (MP-ASI) in the Japanese Hamlet of Margomulyo Village in Bojonegoro Regency.

7. Foods or drinks that can add breast milk according to mothers who have babies under 2 years in theJapanese Hamlet of Margomulyo Village, Bojonegoro Regency.

8. Opinions about MP-ASI before the age of 6 months according to mothers who have babies under 2 years in Japanese Hamlet Margomulyo Village, Bojonegoro Regency.

Distribution of characteristics of respondents

Table 4.1

Characteristics of mother informants who have children aged 2 years and under In the Japanese Hamlet, Margomulyo Village, Bojonegoro Regency

\begin{tabular}{cccccccc}
\hline No & Informan & Age & work & $\begin{array}{c}\text { Last } \\
\text { Education }\end{array}$ & $\begin{array}{c}\text { Number } \\
\text { of } \\
\text { children }\end{array}$ & $\begin{array}{c}\text { The age of } \\
\text { the last } \\
\text { child }\end{array}$ & Method \\
\hline $\mathbf{1}$ & Informan 1 & 24 & IRT & SMA & 3 & 6 month & WM \\
\hline $\mathbf{2}$ & Informan 2 & 24 & IRT & SMA & 2 & 6 month & WM \\
\hline $\mathbf{3}$ & Informan 3 & 26 & IRT & SMA & 2 & 7 month & WM \\
\hline $\mathbf{4}$ & Informan 4 & 28 & IRT & SMA & 2 & 6 month & WM \\
\hline $\mathbf{5}$ & Informan 5 & 25 & IRT & SMA & 2 & 8 month & WM \\
\hline $\mathbf{6}$ & Informan 6 & 31 & IRT & SMA & 4 & 1,8 yo & WM \\
\hline $\mathbf{7}$ & Informan 7 & 27 & IRT & SMA & 2 & 9 month & WM \\
\hline $\mathbf{8}$ & Informan 8 & 29 & IRT & SMA & 2 & 6 month & WM \\
\hline $\mathbf{9}$ & Informan 9 & 28 & IRT & SMA & 2 & 8 month & WM \\
\hline $\mathbf{1 0}$ & $\begin{array}{c}\text { Informan } \\
10\end{array}$ & 24 & employee & SMK & 2 & 7 bulan & WM \\
\hline $\mathbf{1 1}$ & $\begin{array}{c}\text { Informan } \\
11\end{array}$ & 26 & employee & SMK & 2 & 1,9 yo & WM \\
\hline $\mathbf{1 2}$ & $\begin{array}{c}\text { Informan } \\
12\end{array}$ & 33 & PNS & SMA & 3 & 10 month & WM \\
\hline $\mathbf{1 3}$ & $\begin{array}{c}\text { Informan } \\
13\end{array}$ & 30 & IRT & SMA & 2 & 6 month & WM \\
\hline $\mathbf{1 4}$ & $\begin{array}{c}\text { Informan } \\
14\end{array}$ & 31 & IRT & SMA & 3 & 6,5 month & WM \\
\hline $\mathbf{1 5}$ & $\begin{array}{c}\text { Informan } \\
15\end{array}$ & 18 & IRT & SMA & 3 & 1,9 yo & WM \\
\hline & & & & & & \\
\hline
\end{tabular}

\section{Characteristics of mothers who have children aged 2 years and underBased on age (year)}

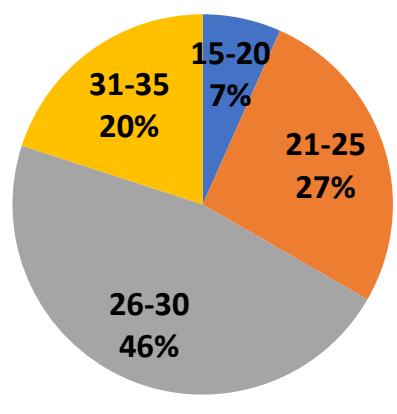

Characteristics of mothers informants who have babies aged 2 years and under are 15 people with the youngest age 18 years and the oldest age is 33 years. 


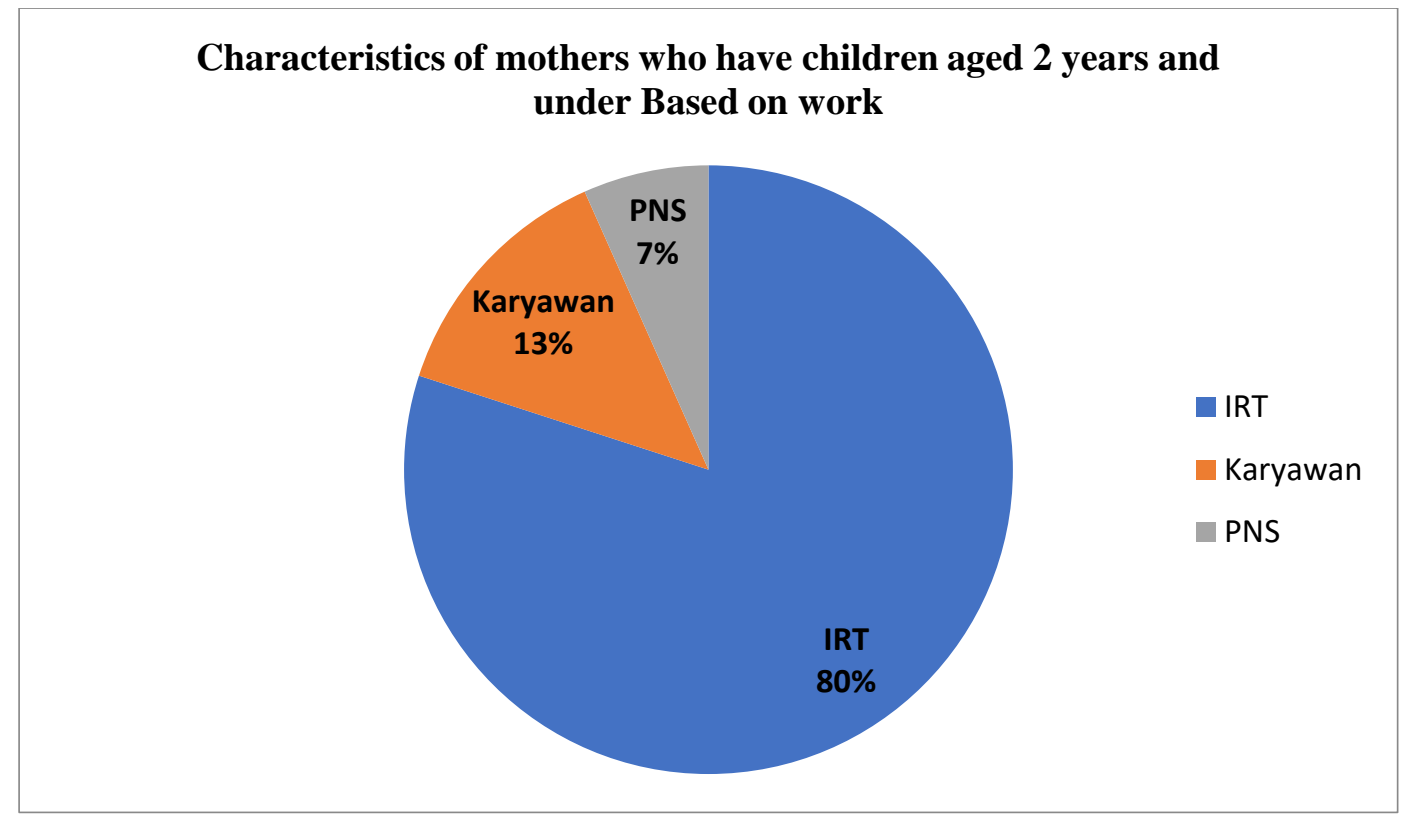

Characteristics of mother informants who have babies aged 2 years and under are 15 based on work. The average informant's job is housewife, 1 is a civil servant (teacher) and 2 employees are in the market.

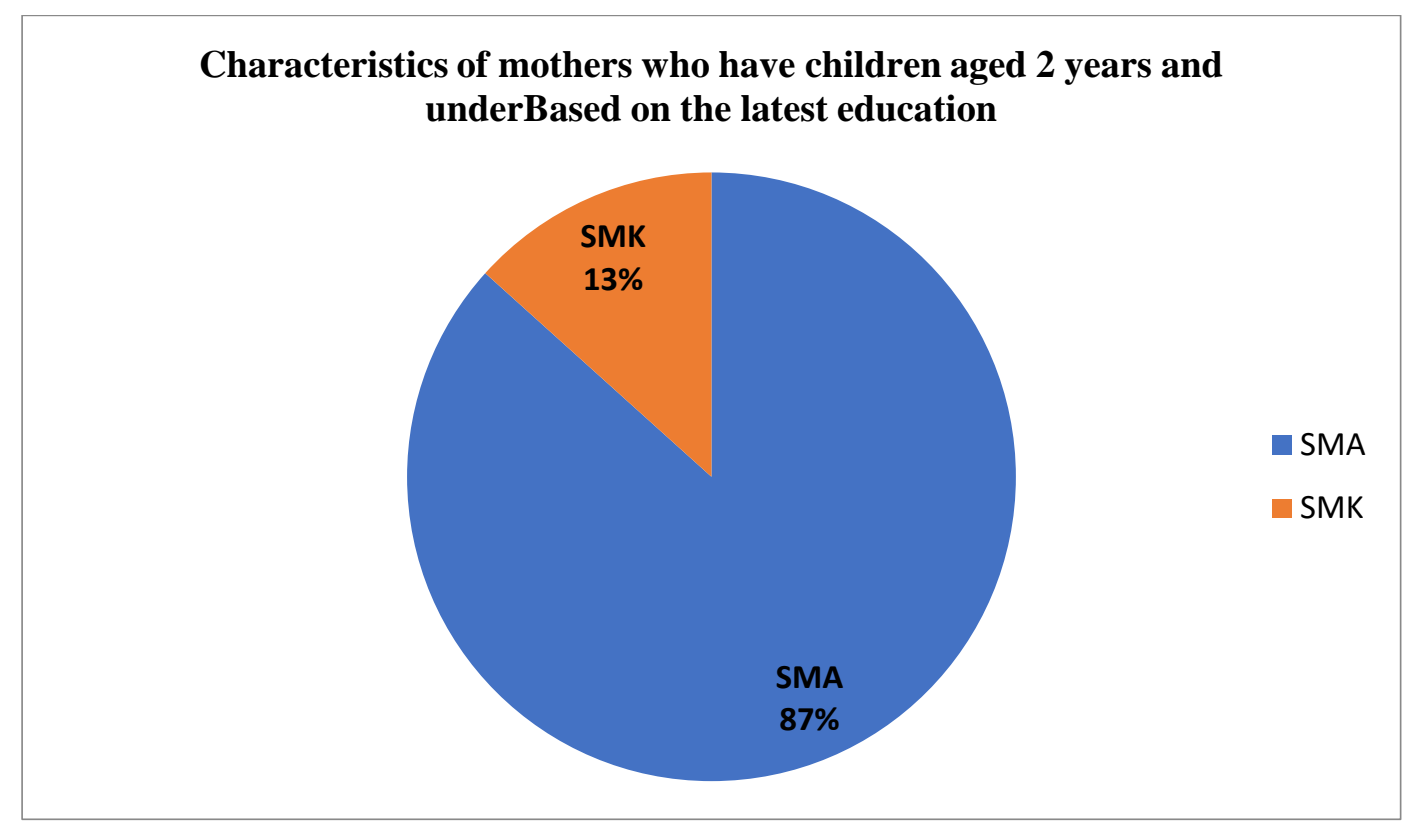

The characteristics of mother informants who have babies aged 2 years and under are 15 people with informant education graduating from high school / vocational school. 


\section{Characteristics of mothers who have children aged 2 years and under Based on the number of children}

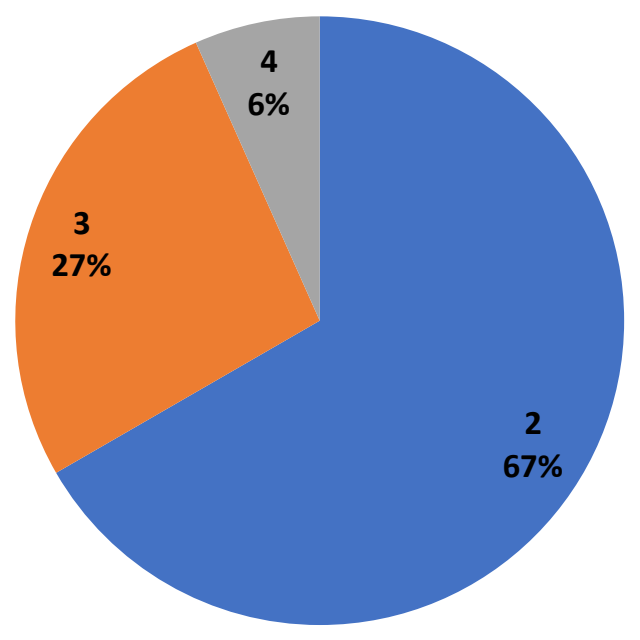

The characteristics of mother informants who have babies aged 2 years and under are 15 people with a large number of children totaling 2 children.

Characteristics of mothers who have children aged 2 years and under Based on the age of the last child (month)

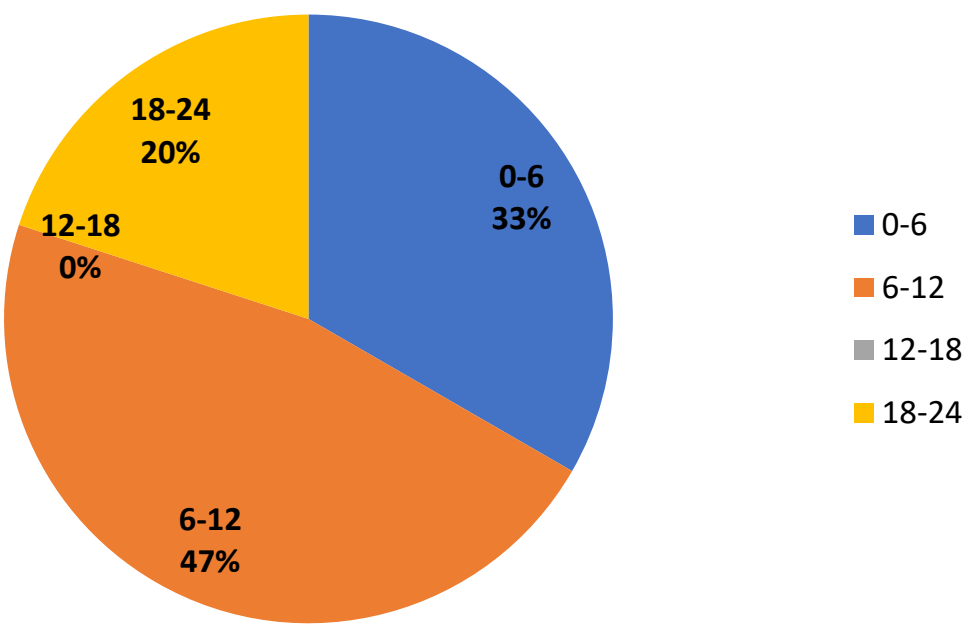

The characteristics of mother informants who have babies aged 2 years and under are 15 people who have the most children aged $6-12$ months.

Table 4.2

Characteristics of Triangulation of Health Workers In the Japanese Hamlet, Margomulyo Village, Bojonegoro Regency

\begin{tabular}{ccccccc}
\hline No & Informan & Age & Last Education & Work & length of work & Method \\
\hline $\mathbf{1}$ & Officer 1 & 35 & midwife & village midwife & 8 yo & WM \\
\hline $\mathbf{2}$ & Officer 2 & 30 & SMA & Kader & 8 tahun & WM \\
\hline
\end{tabular}




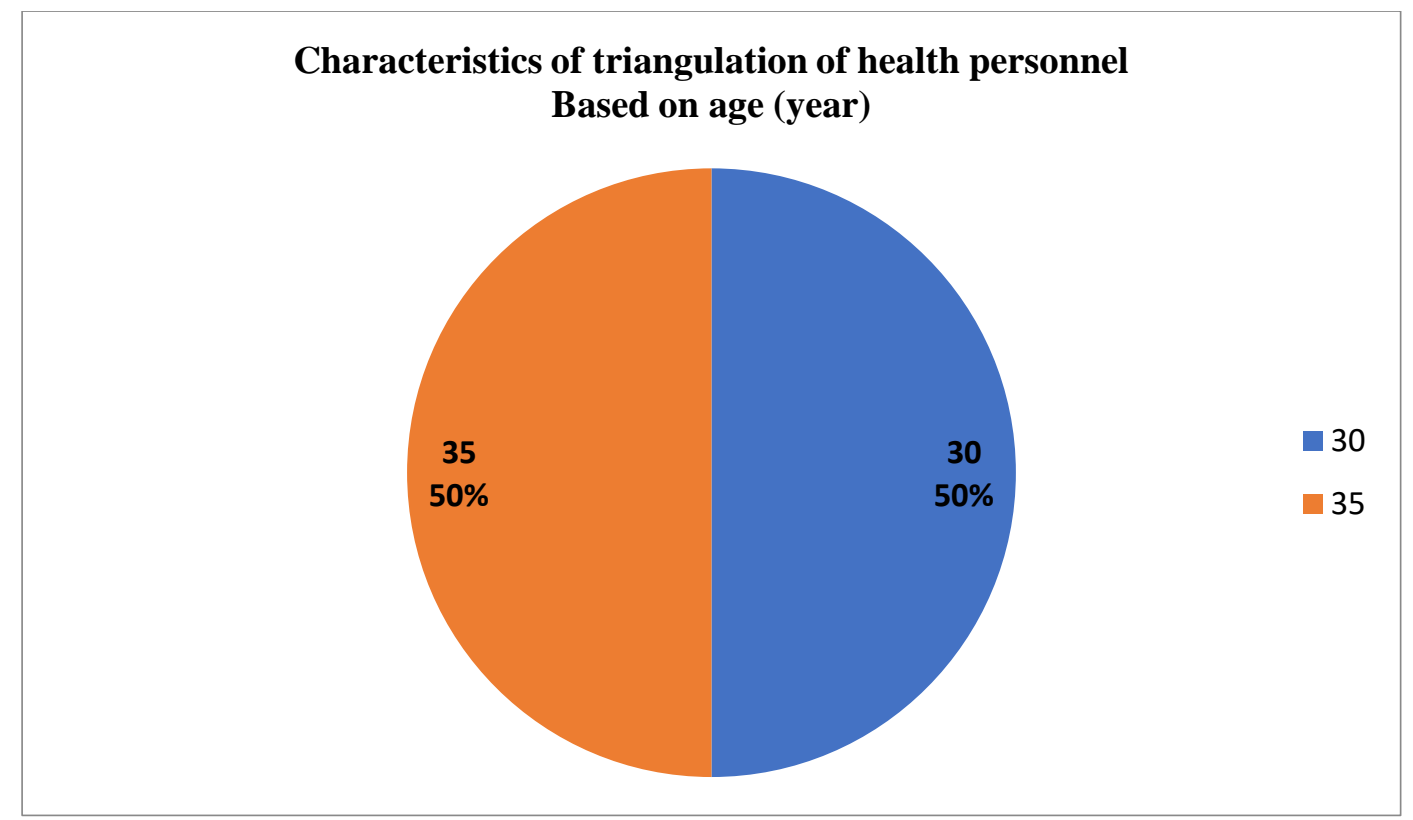

The characteristics of triangulation from health workers are 2 people with the youngest age of 30 years and the oldest age is 35 years.

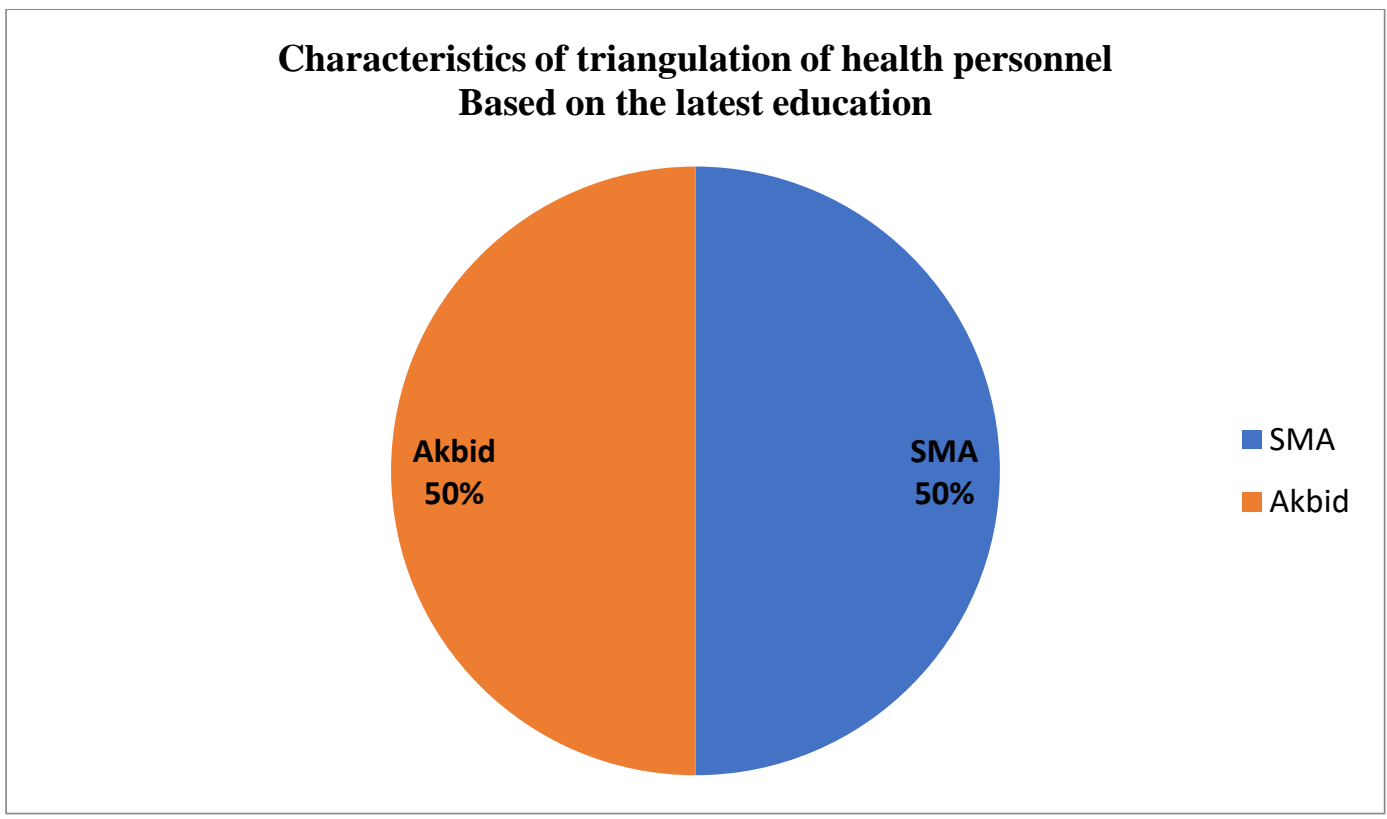

The characteristics of triangulation from health workers were 2 people with the latest education from High School and Midwifery Academy. 


\section{Characteristics of triangulation of health personnel Based on work / position}

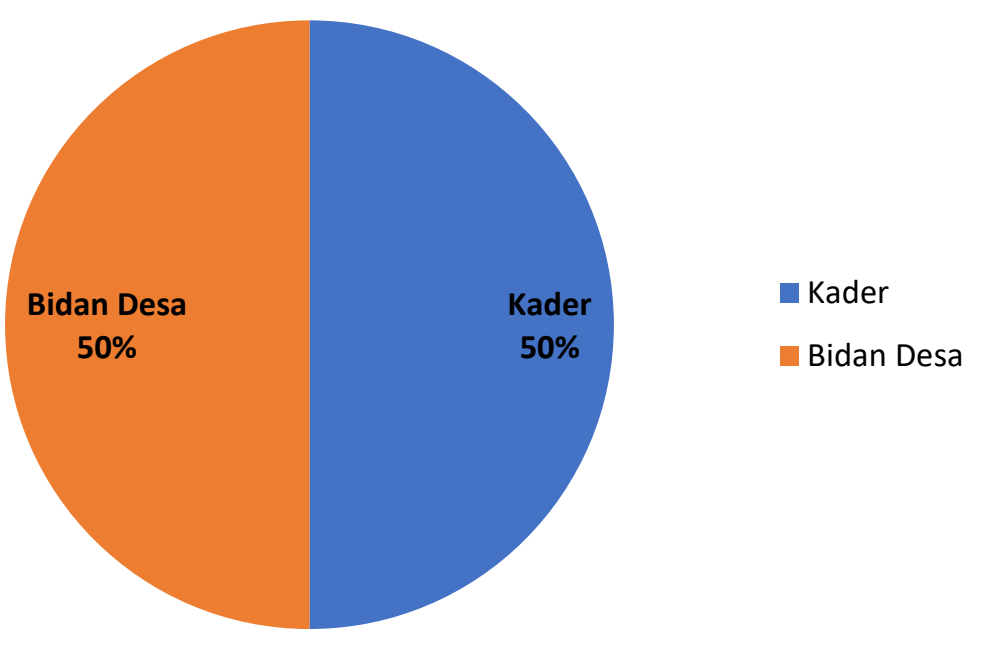

The characteristics of triangulation from health workers are 2 people with work as a village midwife totaling 1 person and a cadre of 1 person.

\section{Characteristics of triangulation of health personnel Based on working time}

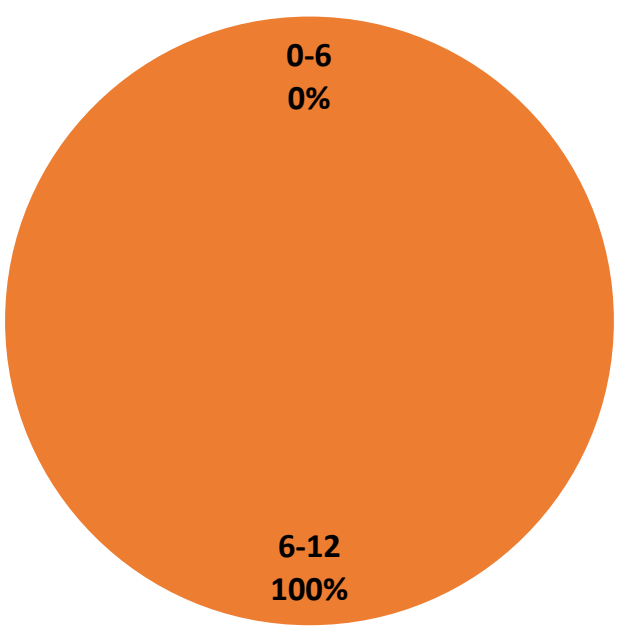

The triangulation characteristics of the health workers were 2 people, with a length of time working at the Margomulyo Health Center for 8 years and at the posyandu for 8 years.

\section{DISCUSSION}

Mother's knowledge about giving exclusive breastfeeding in Japanese Hamlet, Margomulyo Village, Bojonegoro Regency

From the results of the study it can be seen that mothers who provide exclusive breastfeeding have more knowledge, especially about breast milk, than mothers who do not exclusively breastfeed. Although there is a small proportion of informants who do not provide ASI exclusively have knowledge of breastfeeding but are still few and limited. As at the time the author wanted to find out to what extent the mother's knowledge about how long babies should only be given breast milk. Only a small number of mothers know that giving only breast milk is for 6 months, including all mothers who exclusively breastfeed. 
This is in accordance with the Snehandu B. Karr Behavior theory in Notoatmodjo (2009) which states that behavior will be influenced by the presence or absence of health information or accessibility (information) (Notoatmodjo, 2009).

\section{Mother's opinion regarding the provision of Exclusive ASI in Japanese Hamlet, Margomulyo Village, Bojonegoro Regency}

The theme of the development of the exclusive ASI program was built from sub-themes, namely developments in 2016 and in 2017. In this sub-theme shows the development of exclusive ASI programs as conveyed by informants in my opinion, breastfeeding is the best for babies, because from the family breast milk is recommended from small. He said that when I drink breast milk it's rarely sick "(Informant 3).

Exclusive breastfeeding is a government program for achieving healthy and safe babies. The program prevents the risk of illness in infants (Depkes RI, 2014).

\section{The correct technique for breastfeeding is for mothers who have babies under 2 years in the Japanese Hamlet of Margomulyo Village, Bojonegoro Regency}

The provision of ASI has not been optimal by mothers, even though there is an indication that there is a growing number of mothers who do not give their milk. This is due to the limitation of knowledge and skills of health workers in counseling on how to exclusively breastfeed and how to breastfeed properly. Soetjiningsih (2010).

From the results of the study, it was found that mothers who did not provide exclusive breastfeeding also found that they did not know how to breastfeed correctly, a small percentage already knew about how to breastfeed properly, "The nate is tilted, you guys are picked up by the contone, but the roar is very practical" (I've heard and also given an example, but can't yet) (while laughing at the friend next door) "The baby is faced with his mother's stomach, mother, the face of the baby facing mother's breast" (informant 6) It is different from the statement from the Midwife of the Regional Government of Margomulyo Village who may be due to certain reasons, which said that counseling had been routinely conducted every time the posyandu. This is different from the findings that say there has never been counseling about Exclusive Breastfeeding and how to breastfeed properly, both in groups and individuals. This is supported by the mother's knowledge about breastfeeding which is still very lacking.

\section{The time allocation for babies may be given complementary foods in Japanese Hamlet, Margomulyo Village, Bojonegoro Regency}

The theme used in supporting the course of the exclusive ASI program was built on the subtheme of counseling about the allocation of time when infants may be given complementary foods. This is in accordance with the informant's statement 1 which explains "six months and over, because if under six months, the intestines are not as strong as we are adults, still weak" (informant 7) "Six months and above, because the teeth have started to grow too, hahahaha" (informant 6) Disseminating Communication, Information and Education (IEC) about exclusive breastfeeding both individuals and groups is a form of counseling that can be done for exclusive breastfeeding (Depkes, 2012).

Indeed, in the research area there are many traditions that are still inherent in society. Newborn babies have been fed bananas, given water, given tea every day and some of them and some of them think as long as they are still breastfeeding their baby does not matter if they give formula milk or other foods. This is also related to the low level of knowledge they have about Exclusive Breastfeeding.

\section{Advantages of Exclusive ASI according to mothers who have babies under 2 years in the Japanese} Hamlet of Margomulyo Village, Bojonegoro Regency

The theme of the benefits of the exclusive breastfeeding program was built on sub-themes of positive impact on health workers as well as positive impact for breastfeeding mothers as the informant explained, "which is definitely nice to be sterile, relaxed, not having to sleep at night, not having to make milk, boil all milk bottles "(informant 3) Other informants also explained that they did not fully know about ASI's benefits, along with the explanation:

"I don't really know the kula (me) mbak, I don't complete the problem (probing: then what is the younger sibling giving me?) Yes I give water to mbak, no fuss anymore yow no loro (sick)" (Informant 6) "How 
come the milk powder is exclusive, bro, why do you want to mix it up and mix it up with your milk, banana, toyo, bro?" (I'm not exclusive, bro, I give you milk, but I'm mixed with other than breast milk, like a banana, water, so) (Informant 15) Mother's milk is the only perfect food to guarantee the growth of babies in the first six months. In addition, in the correct breastfeeding process, the baby will get good physical, emotional and spiritual development in his life (Saleha, 2009).

According to the author, more precisely information about breastfeeding because the information provided is incomplete, only recommends that after giving birth later the mother should give ASI without notifying the benefits and benefits. From the results above, counseling on Exclusive ASI is still not maximal.

\section{Food provided by the mother for the ASI (MP-ASI) companion in the Japanese Hamlet of Margomulyo Village, Bojonegoro Regency}

The concept of breastfeeding the Samin community is an obligation for a mother. The Samin community views breast milk as a liquid, and functions only as a drink and therefore needs to be added in the form of water, bananas and porridge to babies. Where additional addition to breast milk is perceived as food, it is hoped to introduce Samin culture in infants. This concept is inseparable from the influence of hereditary habits in terms of behavior ranging from pregnancy, childbirth, parenting and those around the mother. The Samin community has provided breast milk to infants, even though it is not in accordance with the medical concept. as conveyed by the informant 3 "given the banana and the rice was cooked so it has been drinking water" (informant 9 original Brebes)

"I don't give Banana Ma'am, just give me a sun. Four months already given "(informant 10).

There are several factors that influence the success of exclusive breastfeeding, one of which is the provision of complementary breastfeeding in infants (Arini, 2012).

The research findings say that counseling on exclusive breastfeeding has never been done. Counseling is only done individually when conducting a pregnancy checkup.

\section{Food or drinks that can add breast milk according to mothers who have babies under 2 years in Japanese Hamlet Margomulyo Village, Bojonegoro Regency}

From the results of the study it can be seen that mothers who have more knowledge especially about food and beverages that can produce breast milk. Although there is a small number of informants who are still not fluent in the pronunciation of the names of foods that can add milk. As when the author wanted to find out to what extent the mother's knowledge of food that could add breast milk, one of the informants replied, "Besides vegetables and nuts, fish are also good for mothers who are breastfeeding because fish can make milk sweet, said my parents are so "(Informant 12) Mother's milk (ASI) is the best life liquid that is needed by babies. ASI contains various substances that are important for baby's growth and according to their needs. However, not all mothers want to breastfeed their babies for various reasons. For example, fear of being fat, busy, saggy breasts and so on (Reni F, 2014).

On the other hand, there are also mothers who want to breastfeed their babies but experience problems. Usually the milk does not want to come out or the production is not smooth.

\section{Opinions about MP-ASI before 6 months of age according to mothers who have babies under 2 years in Japanese Hamlet Margomulyo Village, Bojonegoro Regency}

The things that are believed by someone play an important role in making decisions. As well as in exclusive breastfeeding, mothers who exclusively breastfeed their babies believe that breast milk is the best for their babies, while also believing that the milk given is sufficient for their babies.

In contrast to mothers who did not exclusively provide breastfeeding, although some of them knew about exclusive breastfeeding, the values and beliefs they held were still very strong, so they were more dominant in influencing decisions. For example, their belief that babies who cry often indicates that babies are still hungry because the milk they provide is not enough and needs to be supplemented with the provision of formula milk or other supplementary foods, as the informant revealed, "my child is 3 months old and has eaten porridge" (Informant 4) "if I start at 4 months I have started to give a little like a team porridge, sun, have a little study" (informant 6) Nutrients contained in breast milk include: fat, carbohydrates, protein, salt, minerals, and vitamins. ASI provides all the nutritional and energy needs of infants up to the age of six months (Dewi et al., 2014). 
Indeed, in the research area there are many traditions that are still inherent in society. Newborns have been fed bananas, given water and even tea every day and some of them think as long as they are still breastfeeding their baby does not matter if they give formula milk or other foods. This is also related to the low level of knowledge they have about Exclusive Breastfeeding.

\section{CONCLUSION}

The results of the study show that local beliefs and culture influence exclusive breastfeeding and will have less impact on both breastfeeding mothers and infants. In the process of implementing this research are influenced by several factors including internal factors and external factors. The internal factors include maternal characteristics (age, parity, education, work), knowledge, trust while external factors include the support of health workers (counseling, policies, recording and reporting systems) and family support.

The characteristics of the informants were between 18-33 years old, on average had 2 children, the education level was mostly high school / vocational school and most of them were housewives. Knowledge of exclusive breastfeeding is still lacking. This can be seen from the fact that there are still many mothers who do not exclusively breastfeed due to the habit of giving food and drinks other than breast milk to newborns and the habit of giving complementary foods to breast milk before a 6-monthold baby. Beliefs relating to food and drinks given to newborns still exist because almost all mothers provide drinks other than breast milk such as water, tea, bananas, biscuits, etc. to newborns.

Counseling about exclusive breastfeeding is still not carried out optimally by health workers because there are no special funds for the exclusive breastfeeding program and also there is no motivation from officers, especially nutrition officers. Some family support, especially husbands, is still not available to mothers who are pregnant. This is due to the lack of husband's knowledge about breast milk and also the busyness of the husband who has to work and is rarely at home.

The low inhibiting factor about exclusive breastfeeding coverage is the lack of officers about exclusive breastfeeding, there is still a culture related to maternal knowledge about exclusive breastfeeding, a lack of counseling from health workers with breastfeeding that applies in the community.

\section{REFERENCES}

Arini, H. (2012). Mengapa Seorang Ibu Harus Menyusu. Jakarta: Salemba.

Astutik Yuli Reni, (2014). Payudara dan Laktasi. Jakarta: Salemba Medika.

Dewi Lia dkk, (2014). Asuhan Kebidanan Pada Masa Nifas. Jakarta: Salemba Medika.

Reni Fahriani dkk, (2014). Faktor yang Mempengaruhi Pemberian ASI Eksklusif pada Bayi Cukup Bulan yang Dilakukan Inisiasi Menyusu Dini (IMD). https://jurnal.unimus.ac.id. Diunduh pada Tanggal 12 Juli 2016. Jam 19.30 WIB.

Saleha, (2009). Asuhan Kebidanan Neonatus, bayi dan balita: Jakarta, Salemba Medika.

Notoatmodjo, S. (2009). Pendidikan dan Perilaku Kesehatan. Jakarta: Rineka Cipta.

Saleha, (2012). Asuhan Kebidanan Neonatus, bayi dan balita: Jakarta, Salemba Medika.

Maya Fitria, (2011). Faktor-faktor yang memengaruhi pemberian ASI Eksklusif. https://ejurnal.library.usu.ac.id. Diunduh pada Tanggal 12 Juli 2016. Jam 19.35 WIB.

Departemen Kesehatan, (2012). Profil Kesehatan Indonesia. Jakarta: Kemenkes RI.

Soetjiningsih. (2010). Tumbuh Kembang Anak. Jakarta: EGC.

Departemen Kesehatan, (2014). Profil Kesehatan Indonesia. Jakarta: Kemenkes RI. 